University of Nebraska - Lincoln

DigitalCommons@University of Nebraska - Lincoln

\title{
Structure-Activity Relationships of 33 Carboxamides as Toxicants Against Female Aedes aegypti (Diptera: Culicidae)
}

\author{
Julia Pridgeon \\ USDA-ARS \\ James J. Becnel \\ USDA-ARS, James.Becnel@ars.usda.gov \\ Ulrich R. Bernier \\ University of Florida, ubernier@gainesville.usda.ufl.edu \\ Gary G. Clark \\ USDA-ARS
}

Kenneth J. Linthicum

USDA-ARS

Follow this and additional works at: https://digitalcommons.unl.edu/usdaarsfacpub

Part of the Agricultural Science Commons

Pridgeon, Julia; Becnel, James J.; Bernier, Ulrich R.; Clark, Gary G.; and Linthicum, Kenneth J., "StructureActivity Relationships of 33 Carboxamides as Toxicants Against Female Aedes aegypti (Diptera: Culicidae)" (2010). Publications from USDA-ARS / UNL Faculty. 965.

https://digitalcommons.unl.edu/usdaarsfacpub/965

This Article is brought to you for free and open access by the U.S. Department of Agriculture: Agricultural Research Service, Lincoln, Nebraska at DigitalCommons@University of Nebraska - Lincoln. It has been accepted for inclusion in Publications from USDA-ARS / UNL Faculty by an authorized administrator of DigitalCommons@University of Nebraska - Lincoln. 


\title{
Structure-Activity Relationships of 33 Carboxamides as Toxicants Against Female Aedes aegypti (Diptera: Culicidae)
}

\author{
JULIA W. PRIDGEON, ${ }^{1}$ JAMES J. BECNEL, ULRICH R. BERNIER, GARY G. CLARK, \\ AND KENNETH J. LINTHICUM
}

Center for Medical, Agricultural, and Veterinary Entomology, USDA-ARS, 1600 SW 23rd Dr., Gainesville, FL 32608

J. Med. Entomol. 47(2): 172-178 (2010); DOI: 10.1603/ME08265

\begin{abstract}
Aedes aegypti L. is the primary vector of dengue and yellow fever viruses, and use of aerosolized insecticides is one of the primary ways to control this medically important mosquito. However, few new insecticides have been developed for mosquito control in recent years. As a part of our effort to search for new insecticides to control mosquitoes, toxicities of 33 carboxamides were evaluated against female A. aegypti by topical application. This group included nine different categories of compounds, namely benzamides, phenyl-propenamides, propanamides, butanamides, butenamides, pentanamides, pentenamides, hexanamides, and hexenamides, that exhibited varying levels of toxicity against this mosquito species. The most toxic compound tested was hexahydro-1-(1-oxohexyl)$1 \mathrm{H}$-azepine, with a $24-\mathrm{h} \mathrm{LD}_{50}$ value of $0.4 \mu \mathrm{g}$ per mosquito, whereas the most toxic compound at the $\mathrm{LD}_{95}$ level was N-ethyl-2-methyl-N-phenyl-benzamide (1.82 $\mu \mathrm{g}$ per mosquito). The least toxic compound was N,N-bis (2-methylpropyl)-3-phenyl-2-propenamide, with $\mathrm{LD}_{50}$ and $\mathrm{LD}_{95}$ values of 15.66 and $72.07 \mu \mathrm{g}$ per mosquito, respectively. Results from this initial study may prove useful in guiding further carboxamide modifications for the development of potential new insecticides.
\end{abstract}

KEY WORDS carboxamide, mosquito control, dengue, Aedes aegypti, insecticide

Aedes aegypti L. (Diptera: Culicidae) transmits several viral pathogens of humans, including yellow fever (Gillett and Ross 1955, Philip 1962, Soper 1967, Aitken et al. 1977) and dengue (Mattingly 1967, Rudnick 1967, Coleman and McLean 1973, Degallier et al. 1988), which can cause severe human morbidity and mortality. Although there is a safe and effective vaccine for the yellow fever virus, epidemic transmission still occurs in Africa with sporadic cases in South America (Vasconcelos et al. 2001; de Filippis et al. 2002; Valero 2003; Onyango et al. 2004a, b). Dengue is the most important arboviral disease in the world and can cause an undifferentiated fever, dengue fever, dengue hemorrhagic fever, or dengue shock syndrome (Malavige et al. 2004). Annually, dengue epidemics account for several million cases with thousands of deaths worldwide (Teixeira Mda et al. 2005).

Mosquito control in many countries relies primarily on insecticides. After the introduction of synthetic organic insecticides in the 1940s and 1950s, Ae. aegypti was eradicated from many countries in the Americas. The Pan American Health Organization initiated a campaign to use DDT to eradicate Ae. aegypti in the

The use of trade, firm, or corporation names in this publication is for the information and convenience of the reader. Such use does not constitute an official endorsement or approval by the U.S. Department of Agriculture or the Agricultural Research Service of any product or service to the exclusion of others that may be suitable.

${ }^{2}$ Corresponding author, e-mail: julia.pridgeon@ars.usda.gov.
Western Hemisphere in the late 1940s (Pinto Severo 1955, Fouque and Carinci 1996). By 1972, Ae. aegypti had been eradicated from $73 \%$ of the land area and 19 countries (Gubler 1989). However, insecticide resistance developed (Brown and Pal 1971), and the campaign ended in 1972 before the goal of eradication was achieved. Generally, widespread resistance to insecticides previously used to control mosquitoes has resulted in significant loss of efficacy against several disease vectors (Hamdan et al. 2005, Yaicharoen et al. 2005, Cui et al. 2006, Flores et al. 2006, Jirakanjanakit et al. 2007). Therefore, there is urgent need for the development of additional insecticide classes with novel modes of action to maintain control of pathogen-transmitting mosquitoes.

The use of repellents is a common personal protection method to prevent mosquito bites. During the last $60 \mathrm{yr}$, $>25,000$ compounds have been evaluated as toxicants and repellents against mosquitoes at the USDA's Center for Medical, Agricultural and Veterinary Entomology (CMAVE) in Gainesville, FL (Xue et al. 2001). Recently, N,N-diethyl-3-methyl-benzamide (DEET; a carboxamide) has been reported to possess larvicidal and adulticidal activities against mosquitoes (Xue et al. 2003, Licciardi et al. 2006), suggesting that carboxamides might be developed as toxicants for mosquito control. As part of our effort to search for new repellents for mosquito control, different piperidines (Katritzky et al. 2008) and carboxamides were synthesized for further optimization 
as repellents. The structure-activity relationship of the piperidines as toxicants has been reported earlier (Pridgeon et al. 2007). However, it is not clear whether these carboxamides have insecticidal activity. In this study, we evaluated the insecticidal toxicity of 33 carboxamides against female Ae. aegypti. Results from this initial study will be useful for guiding further work on carboxamides for the development of novel efficacious insecticides.

\section{Materials and Methods}

Mosquitoes. The Orlando strain of A. aegypti was reared in the insectary of the Mosquito and Fly Research Unit at CMAVE, USDA-ARS. This strain has been colonized at CMAVE since 1952. Female mosquitoes were used for all experiments. Eggs were hatched by placing a section of a paper towel with eggs in a flask filled with 1 liter of distilled water containing $40 \mathrm{mg}$ of larval diet (3:2 brewer's yeast:liver powder; MP Biomedicals, Irvine, CA). The larvae from these eggs were held overnight in the flask, and 200 were transferred to a 4-liter plastic tray containing 2 liters of deionized water. Larval diet was added to each tray according to the following schedule: day 1, $80 \mathrm{mg}$; day 3, $40 \mathrm{mg}$; day 4, $80 \mathrm{mg}$; day 5, $120 \mathrm{mg}$; and day 6, 150 mg. Mosquitoes were reared in an environmental chamber set with a temperature profile representing a simulated temperate latitude summer day regime (ranging from 22 to $30^{\circ} \mathrm{C}$ ) and $80 \% \mathrm{RH}$. Incandescent lighting was set to a crepuscular profile with a photoperiod of 14:10 (L:D) h, including $2 \mathrm{~h}$ of simulated dawn and $2 \mathrm{~h}$ of simulated dusk. Adults were held in a screened cage and provided $10 \%$ sucrose ad libitum. Bovine blood in $1 \%$ heparin placed in collagen sausage casings (The Sausage Maker, Buffalo, NY) was warmed to $37^{\circ} \mathrm{C}$ and provided to the females twice a week. Eggs were collected on paper towels (Vasco Brands, Elmira, NY) that lined the rim of water containers. These egg-laden papers were air dried at $27^{\circ} \mathrm{C}$ and $80 \% \mathrm{RH}$ for $24 \mathrm{~h}$ and stored in containers with $100 \%$ RH for $3-30 \mathrm{~d}$.

Chemicals and Bioassays. All experimental carboxamides were synthesized, and the identities were confirmed by mass spectrometry by the Center for Heterocyclic Compounds at the University of Florida (Figs. 1-8). DEET was used as a reference control and purchased from Chem Service (Chem Service, West Chester, PA). Each chemical was serially diluted in acetone and topically applied to individual mosquitoes. Before application, 5- to 7-d-old females were anesthetized for $\approx 30 \mathrm{~s}$ with $\mathrm{CO}_{2}$ and placed on a $4^{\circ} \mathrm{C}$ chill table (BioQuip Products, Rancho Dominguez, CA). A $0.5-\mu$ l droplet of insecticide solution was applied to the dorsal surface of thorax using a 700 series syringe and a PB 600 repeating dispenser (Hamilton, Reno, NV). Six concentrations providing a mortality range of $0-100 \%$ were applied to 25-30 females per insecticide concentration. Tests were replicated three times. Control treatments with $0.5 \mu \mathrm{l}$ of acetone alone produced $<10 \%$ mortality in the control mosquitoes. After treatment, mosquitoes were kept in plastic cups and supplied with $10 \%$ sucrose solution for $24 \mathrm{~h}$ when

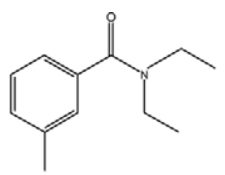

N,N-diethyl-3-methyl-benzamide (DEET)<smiles>CCCCN(CC)C(=O)c1ccccc1C</smiles>

N-butyl-N-ethyl-2-methyl-benzamide<smiles>CCN(C(=O)c1ccccc1C)c1ccccc1</smiles>

N-ethyl-2-methyl-N-phenyl-benzamide<smiles>C=C(C)CN(CC)C(=O)c1ccccc1C</smiles>

N-ethyl-2-methyl-N-(2-methyl-2-propenyl)-benzamide

Fig. 1. Chemical structures of the benzamides.

mortality was recorded. Temperature and relative humidity were maintained at $26^{\circ} \mathrm{C}$ and $80 \%$, respectively. Bioassays were conducted at $26^{\circ} \mathrm{C}$ and $80 \% \mathrm{RH}$ and replicated three times. Correction of mortality compared with controls was performed using modified Abbott's formula (Abbott 1925). Bioassay data were analyzed using PoloPlus probit analysis software (LeOra Software, Petaluma, CA). A $\chi^{2}$ goodness-of-fit test on dose-response and $\mathrm{LD}_{50} / \mathrm{LD}_{95}$ value estima-

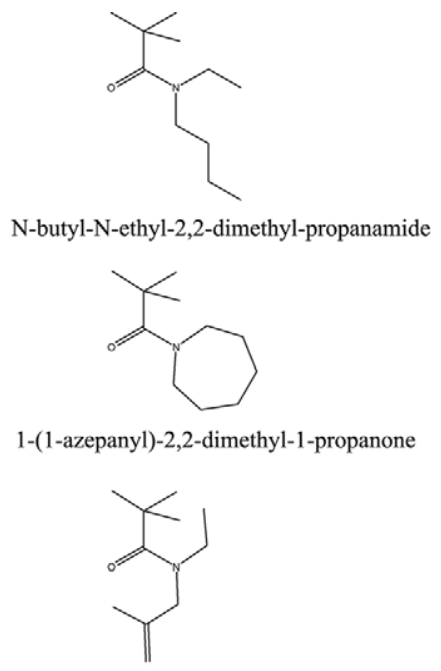

$\mathrm{N}$-ethyl-2,2-dimethyl-N-(2-methyl-2-propenyl)-propanamide

Fig. 2. Chemical structures of the phenyl-propenamides. 
<smiles>CCCCN(CC)C(=O)/C=C/c1ccccc1</smiles>

N-butyl-N-ethyl-3-phenyl-2-propenamide<smiles>CCN(C(=O)/C=C/c1ccccc1)c1ccccc1</smiles>

N-ethyl-N,3-diphenyl-2-propenamide<smiles>CC(C)CN(CC(C)C)C(=O)/C=C/c1ccccc1</smiles>

N,N-bis(2-methylpropyl)-3-phenyl-2-propenamide

Fig. 3. Chemical structures of the propanamides.

tion were performed using the same PoloPlus program (Pridgeon et al. 2007). Toxicity of compound is considered significantly different when the $95 \%$ confidence interval (CI) fails to overlap.

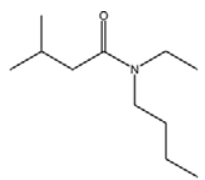

N-butyl-N-ethyl-3-methyl-butanamide<smiles>CC(C)CC(=O)C(CC(C)C)CC(C)C</smiles>

N,N-diisobutyl-3-methyl-butanamide<smiles>CCC(C(=O)CC(C)C)C1CCCCC1</smiles>

$\mathrm{N}$-cyclohexyl-N-ethyl-3-methyl-butanamide<smiles>CCCCC(CC)C(=O)C(CC)CC</smiles>

N-butyl-N,2-diethyl-butanamide

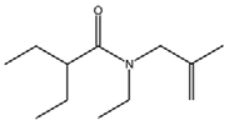

N,2-diethyl-N-(2-methyl-2-propenyl)-butanamide

Fig. 4. Chemical structures of the butanamides.

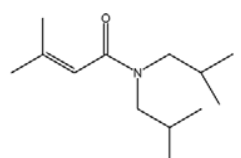

N,N-diisobutyl-3-methyl-crotonamide<smiles>CC(C)=CC(=O)N1CCCCCC1</smiles>

Hexahydro-1-(3-methylcrotonoyl)-1H-azepine<smiles>C=C(C)CN(CC)C(=O)C=C(C)C</smiles>

$\mathrm{N}$-ethyl-3-methyl-N-(2-methyl-2-propenyl)-2-butenamide<smiles>CCCCN(CC)C(=O)C=C(C)C</smiles>

N-butyl-N-ethyl-3-methyl-2-butenamide

Fig. 5. Chemical structures of the butenamides.

\section{Results and Discussion}

DEET and 3 of the 33 experimental carboxamides tested were benzamide analogs (Fig. 1). Based on $\mathrm{LD}_{50}$ values, the most toxic compound of this group was N-butyl-N-ethyl-2-methyl-benzamide, followed by N-ethyl-2-methyl-N-phenyl-benzamide (Table 1). The least toxic benzamide was $\mathrm{N}$-ethyl-2-methyl-N-

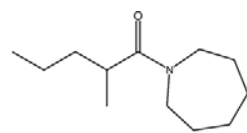

1-(1-azepanyl)-2-methyl-1-pentanamide

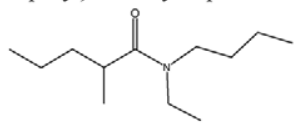

N-butyl-N-ethyl-2-methyl-pentanamide

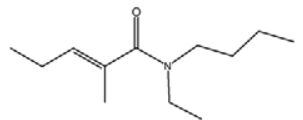

(E)-N-butyl-N-ethyl-2-methyl-2-pentenamide

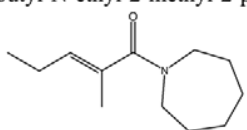

(E)-1-(1-azepanyl)-2-methyl-2-pentenamide

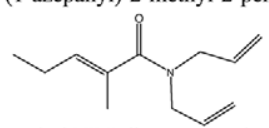

(E)-2-methyl-N,N-di-2-propenyl-2-pentenamide

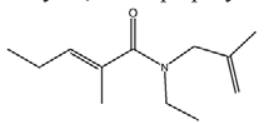

(E)-N-ethyl-2-methyl-N-(2-methyl-2-propenyl)-2-pentenamide

Fig. 6. Chemical structures of the pentanamides and pentenamides. 


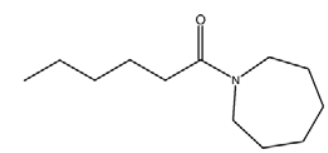

Hexahydro-1-(1-oxohexyl)-1-H-azepine<smiles>CCCCCC(=O)C(CC)CCCC</smiles>

N-butyl-N-ethyl-hexanamide

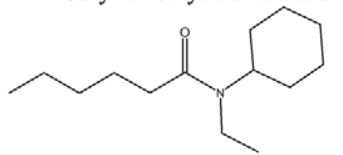

$\mathrm{N}$-cyclohexyl-N-ethyl-hexanamide<smiles>CCCCCC(=O)N(CC)c1ccccc1</smiles>

N-ethyl-N-phenyl-hexanamide<smiles>CCCCCC(=O)N(C)CCCC</smiles>

N-butyl-N-methyl-hexanamide

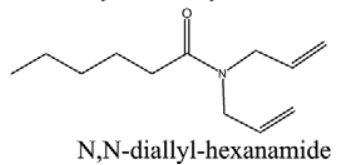

Fig. 7. Chemical structures of the hexanamides.

(2-methyl-2-propenyl)-benzamide. Based on $\mathrm{LD}_{95}$ values, the most toxic benzamide was N-ethyl-2-methyl-Nphenyl-benzamide, followed by N-butyl-N-ethyl-2methyl-benzamide. The least toxic experimental benzamide, slightly less toxic than DEET, was N-ethyl2-methyl-N-(2-methyl-2-propenyl)-benzamide. Our results showed the following structure-activity trend for the three benzamide analogs: N-butyl $\geq \mathrm{N}$-phenyl $>$ $\mathrm{N}$-(2-methyl-2-propenyl).

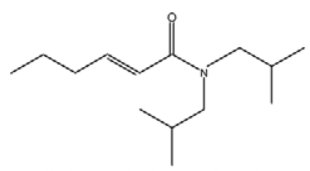

(E)-N,N-di-(2-methylpropyl)-2-hexenamide

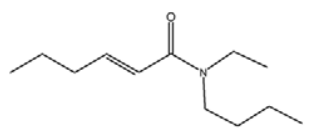

(E)-N-butyl-N-ethyl-2-hexenamide

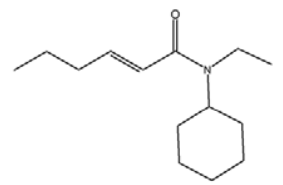

(E)-N-cyclohexyl-N-ethyl-2-hexenamide

Fig. 8. Chemical structures of the hexenamides.
Three of the carboxamides tested were phenyl-propenamide analogs (Fig. 2). Based on $\mathrm{LD}_{50}$ and $\mathrm{LD}_{95}$ values, the most toxic phenyl-propenamide was N-butyl-N-ethyl-3-phenyl-2-propenamide, followed by N-ethyl-N,3-diphenyl-2-propenamide (Table 1). The least toxic compound in this group was $\mathrm{N}, \mathrm{N}$-bis (2-methylpropyl)-3-phenyl-2-propenamide. Our results showed the following structure-activity trends for the phenyl-propenamides: N-butyl $>\mathrm{N}$-phenyl; N-ethyl-N-butyl $>$ N-ethyl-N-phenyl $>\mathrm{N}, \mathrm{N}$-diisobutyl. The structure-activity trend of N-butyl $>$ N-phenyl for the phenyl-propenamide analogues was consistent with the results from the structure-activity analysis of the benzamide analogs.

Three of the carboxamides tested were propanamide analogs (Fig. 3). The most active propanamide was Nbutyl-N-ethyl-2,2-dimethyl-propanamide, followed by 1-(1-azepanyl)-2,2-dimethyl-1-propanone (Table 2). The least toxic propanamide was N-ethyl-2,2-dimethyl$\mathrm{N}$-(2-methyl-2-propenyl)-propanamide. Our results showed the following structure-activity trend for the propanamide: N-butyl $>\mathrm{N}$-azepanyl $>\mathrm{N}$ - (2-methyl-2propenyl). The structure-activity trend of N-butyl $>$ $\mathrm{N}$-(2-methyl-2-propenyl) for the propanamide analogs was consistent with results from the structure-activity analysis of the three benzamide analogs.

Five of the carboxamides tested were butanamide analogs (Fig. 4). The most active butanamide was N-butyl-N,2-diethyl-butanamide, followed by N-butyl-N-ethyl-3-methyl-butanamide and N,N-diisobutyl-3-methyl-butanamide (Table 2). The least toxic butanamide was N,2-diethyl-N-(2-methyl-2-propenyl)-butanamide, followed by N-cyclohexyl-N-ethyl3-methyl-butanamide (Table 2). Our results showed the following structure-activity trends for the butanamide analogs: N-butyl > N-cyclohexyl; N-ethyl-Nbutyl > N,N-diisobutyl > N-ethyl-N-cyclohexyl, $\mathrm{N}$-butyl $>\mathrm{N}$-(2-methyl-2-propenyl). The N-butyl $>$ $\mathrm{N}$-(2-methyl-2-propenyl) structure-activity trend for the butanamides was consistent with results from structure-activity analyses of the propanamide analogs and the benzamide analogs.

Four of the carboxamides tested were 3-methyl-2butenamides (Fig. 5). Based on $\mathrm{LD}_{50}$ values, the most toxic compounds of this group were $\mathrm{N}, \mathrm{N}$-diisobutyl3-methyl-crotonamide and hexahydro-1-(3-methylcrotonoyl)-1H-azepine, followed by N-ethyl-3-methyl$\mathrm{N}$-(2-methyl-2-propenyl)-2-butenamide (Table 2). The least toxic butenamide was N-butyl-N-ethyl-3methyl-2-butenamide. Based on $\mathrm{LD}_{95}$ values, the most toxic compound of this group was hexahydro-1-(3methylcrotonoyl)-1H-azepine, followed by $\mathrm{N}, \mathrm{N}-\mathrm{di}-$ isobutyl-3-methyl-crotonamide and N-ethyl-3-methylN-(2-methyl-2-propenyl)-2-butenamide (Table 2). The least toxic butenamide was N-butyl-N-ethyl-3methyl-2-butenamide. Our results showed the following structure-activity trend for butenamide analogs: $\mathrm{N}$, $\mathrm{N}$-diisobutyl $\geq \mathrm{N}$-azepine $>\mathrm{N}$-ethyl-N-(2-methyl-2propenyl) $>\mathrm{N}$-butyl.

Two pentanamides and four pentenamides (Fig. 6) were synthesized as carboxamides. 1-(1-Azepanyl)-2methyl-1-pentanone exhibited slightly greater activity 
Table 1. Toxicities of benzamides and phenyl-propenamides against adult females of Ae. aegypti

\begin{tabular}{lccrr}
\hline \multicolumn{1}{c}{ Chemical } & $\mathrm{LD}_{50}(95 \% \mathrm{CI})^{a, b}$ & $\mathrm{LD}_{95}(95 \% \mathrm{CI})^{a, b}$ & $\begin{array}{c}\text { Slope } \\
(\mathrm{SE})\end{array}$ & $\chi^{2}$ \\
\hline N,N-diethyl-3-methyl-benzamide (DEET) & $2.69(2.27-3.23)$ & $6.89(5.26-10.83)$ & $4.03(0.60)$ & 1.73 \\
N-butyl-N-ethyl-2-methyl-benzamide & $0.47(0.35-0.63)$ & $3.36(2.15-6.79)$ & $1.93(0.26)$ & 1.25 \\
N-ethyl-2-methyl-N-phenyl-benzamide & $0.59(0.48-0.71)$ & $1.82(1.37-2.87)$ & $3.34(0.45)$ & 3.36 \\
N-ethyl-2-methyl-N-(2-methyl-2-propenyl)-benzamide & $3.14(2.65-3.72)$ & $7.16(5.60-11.19)$ & $4.60(0.77)$ & 0.35 \\
N-butyl-N-ethyl-3-phenyl-2-propenamide & $1.98(1.75-2.26)$ & $4.77(3.84-6.72)$ & $4.30(0.55)$ & 3.61 \\
N-ethyl-N,3-diphenyl-2-propenamide & $3.21(2.07-4.05)$ & $9.78(7.26-19.71)$ & $3.40(0.80)$ & 0.39 \\
N,N-bis (2-methylpropyl)-3-phenyl-2-propenamide & $15.66(8.97-24.64)$ & $72.07(39.73-385.76)$ & $2.48(0.37)$ & 3.82 \\
\hline
\end{tabular}

${ }^{a} \mathrm{LD}_{50}$ and $\mathrm{LD}_{95}$ values are in units of micrograms of pesticide per mosquito.

${ }^{b} 95 \%$ CI, toxicity of repellent is considered significantly different when the $95 \%$ CI fails to overlap.

against female Ae. aegypti compared with N-butyl-Nethyl-2-methyl-pentanamide (Table 3). All four pentenamides showed lower toxicity than the two pentanamides (Table 3). The most active pentenamide was (E)-N-butyl-N-ethyl-2-methyl-2-pentenamide, followed by (E)-1-(1-azepanyl)-2-methyl-2-pentenamide and (E)-2-methyl-N,N-di-2-propenyl-2-pentenamide. The least toxic pentenamide was (E)-N-ethyl-2-methyl-N(2-methyl-2-prpenyl)-2-pentenamide (Table 3). Our results showed the following structure-activity trends: 2-methyl-pentanamide $>$ 2-methyl-2-pentenamide; N-ethyl-N-butyl $>\mathrm{N}$-azepanyl $>\mathrm{N}, \mathrm{N}$-di-2-propenyl $>$ N-ethyl-N-(2-methyl-2-propenyl).

Six hexanamide analogs (Fig. 7) were synthesized. Based on $\mathrm{LD}_{50}$ values, the most toxic compound was hexahydro-1-(1-oxohexyl)-1H-azepine, followed by N-butyl-N-ethyl-hexanamide, N-cyclohexyl-N-ethylhexanamide, and N-ethyl-N-phenyl-hexanamide. The least toxic hexanamide was $\mathrm{N}, \mathrm{N}$-diallyl-hexanamide, followed by N-butyl-N-methyl-hexanamide (Table 3). Based on $\mathrm{LD}_{95}$ values, the most toxic compounds were N-cyclohexyl-N-ethyl-hexanamide and $\mathrm{N}$-ethyl$\mathrm{N}$-phenyl-hexanamide, followed by N-butyl-Nmethyl-hexanamide, N-butyl-N-ethyl-hexanamide, and hexahydro-1-(1-oxohexyl)-1H-azepine. The least toxic hexanamide was $\mathrm{N}, \mathrm{N}$-diallyl-hexanamide (Table 3). Our results showed the following structure-activity trends for the hexanamides: N-azepine $>\mathrm{N}$-ethyl-Nbutyl $>$ N-ethyl-N-cyclohexyl $>$ N-ethyl-N-phenyl $>$
N-methyl-N-butyl $>$ N,N-diallyl; N-butyl $>$ N-cyclohexyl $>\mathrm{N}$-phenyl; N-ethyl $>\mathrm{N}$-methyl.

Three hexenamide analogs (Fig. 8) were synthesized, with the most toxic compound as (E)-N,N-di(2-methylpropyl)-2-hexenamide, followed by (E)-Nbutyl-N-ethyl-2-hexenamide (Table 3). The least toxic of these three analogs was (E)-N-cyclohexyl-Nethyl-2-hexenamide (Table 3). Our results showed the following structure-activity trends for the hexenamide: N,N-di-(2-methylpropanyl) $>$ N-ethyl-N-butyl $>$ N-ethyl-N-cyclohexyl; N-butyl > N-cyclohexyl. The N-butyl $>$ N-cyclohexyl structure-activity trend for the hexenamides was consistent with the results from the structure activity of the hexanamides, propanamides, and benzamide analogs.

Our bioassay results also showed that the doseresponse of Ae. aegypti to the carboxamides tested was statistically normal because the majority of the $\chi^{2}$ values were between 0.10 and 9.49. The critical $\chi^{2}$ values for two-tailed distribution $(\alpha=0.05)$ are 0.10 and $5.99(\mathrm{df}=2), 0.35$ and $7.82(\mathrm{df}=3)$, and 0.71 and $9.49(\mathrm{df}=4)$. The relatively high slope and SE values (Tables 1-3) compared with field mosquitoes (Liu et al. 2004) suggest that our Orlando strain of mosquito was relatively homozygous in response to these carboxamides, whereas the field mosquitoes were relatively heterozygous in response to chemicals (Liu et al. 2004).

Table 2. Toxicities of propanamides, butanamides, and butenamides against adult females of Ae. aegypti

\begin{tabular}{|c|c|c|c|c|}
\hline Chemical & $\begin{array}{c}\mathrm{LD}_{50} \\
(95 \% \mathrm{CI})^{a, b}\end{array}$ & $\mathrm{LD}_{95}(95 \% \mathrm{CI})^{a, b}$ & $\begin{array}{l}\text { Slope } \\
\text { (SE) }\end{array}$ & $x^{2}$ \\
\hline N,N-diethyl-3-methyl-benzamide (DEET) & $2.69(2.27-3.23)$ & $6.89(5.26-0.83)$ & $4.03(0.60)$ & 1.73 \\
\hline N-butyl-N-ethyl-2,2-dimethyl-propanamide & $1.27(0.97-1.71)$ & $9.72(5.81-22.53)$ & $1.86(0.25)$ & 3.20 \\
\hline 1-(1-azepanyl)-2,2-dimethyl-1-propanone & $4.33(3.30-5.28)$ & $12.73(9.32-24.74)$ & $3.51(0.73)$ & 0.58 \\
\hline N-ethyl-2,2-dimethyl-N-(2-methyl-2-propenyl)-propanamide & $9.45(7.50-11.42)$ & $25.64(19.16-46.16)$ & $3.79(0.74)$ & 0.81 \\
\hline N-butyl-N,2-diethyl-butanamide & $0.76(0.38-1.21)$ & $4.02(2.18-24.45)$ & $2.78(0.37)$ & 3.48 \\
\hline N-butyl-N-ethyl-3-methyl-butanamide & $1.50(1.19-1.91)$ & $5.87(4.09-10.34)$ & $2.78(0.36)$ & 1.96 \\
\hline N,N-diisobutyl-3-methyl-butanamide & $2.18(1.74-2.71)$ & $7.54(5.39-13.46)$ & $3.05(0.48)$ & 0.66 \\
\hline N-cyclohexyl-N-ethyl-3-methyl-butanamide & $3.63(2.75-4.20)$ & $8.59(6.53-20.18)$ & $4.39(1.21)$ & 0.13 \\
\hline $\mathrm{N}$,2-diethyl-N-(2-methyl-2-propenyl)-butanamide & $4.29(3.48-5.69)$ & $13.66(8.93-34.98)$ & $3.27(0.67)$ & 0.87 \\
\hline $\mathrm{N}, \mathrm{N}$-di-isobutyl-3-methyl-crotonamide & $1.48(1.06-1.88)$ & $6.23(4.28-13.08)$ & $2.63(0.50)$ & 0.96 \\
\hline Hexahydro-1-(3-methylcrotonoyl)-1H-azepine & $1.59(1.21-1.82)$ & $3.11(2.62-4.67)$ & $5.64(1.33)$ & 0.46 \\
\hline N-ethyl-3-methyl-N-(2-methyl-2-propenyl)-2-butenamide & $2.41(1.94-3.06)$ & $9.84(6.44-22.53)$ & $2.69(0.48)$ & 1.52 \\
\hline N-butyl-N-ethyl-3-methyl-2-butenamide & $4.00(3.08-5.77)$ & $18.21(10.11-88.04)$ & $2.50(0.61)$ & 0.16 \\
\hline
\end{tabular}

${ }^{a} \mathrm{LD}_{50}$ and $\mathrm{LD}_{95}$ values are in units of micrograms of pesticide per mosquito.

${ }^{b} 95 \%$ CI, toxicity of repellent is considered significantly different when the $95 \%$ CI fails to overlap. 
Table 3. Toxicities of pentanamides, pentenamides, hexanamides, and hexenamides against adult females of Ae. aegypti

\begin{tabular}{|c|c|c|c|c|}
\hline Chemical & $\begin{array}{c}\mathrm{LD}_{50} \\
(95 \% \mathrm{CI})^{a, b}\end{array}$ & $\mathrm{LD}_{95}(95 \% \mathrm{CI})^{a, b}$ & $\begin{array}{l}\text { Slope } \\
\text { (SE) }\end{array}$ & $\chi^{2}$ \\
\hline N,N-diethyl-3-methyl-benzamide (DEET) & $2.69(2.27-3.23)$ & $6.89(5.26-10.83)$ & $4.03(0.60)$ & 1.73 \\
\hline 1-(1-azepanyl)-2-methyl-1-pentanone & $0.71(0.52-0.90)$ & $3.32(2.26-6.72)$ & $2.45(0.42)$ & 1.78 \\
\hline N-butyl-N-ethyl-2-methyl-pentanamide & $1.01(0.79-1.27)$ & $4.29(3.00-7.71)$ & $2.62(0.38)$ & 1.23 \\
\hline (E)-N-butyl-N-ethyl-2-methyl-2-pentenamide & $3.13(2.73-3.49)$ & $6.30(5.25-8.91)$ & $5.41(0.95)$ & 0.47 \\
\hline (E)-1-(1-azepanyl)-2-methyl-2-pentenamide & $3.92(3.36-4.41)$ & $7.72(6.37-11.59)$ & $5.58(1.13)$ & 0.10 \\
\hline (E)-2-methyl-N,N-di-2-propenyl-2-pentenamide & $5.77(4.66-6.67)$ & $14.81(11.56-25.16)$ & $4.02(0.81)$ & 0.38 \\
\hline (E)-N-ethyl-2-methyl-N-(2-methyl-2-propenyl)-2-pentenamide & $7.21(6.19-8.01)$ & $12.40(10.68-16.89)$ & $6.98(1.42)$ & 0.27 \\
\hline Hexahydro-1-(1-oxohexyl)-1H-azepine & $0.40(0.20-0.62)$ & $11.40(5.24-56.34)$ & $1.13(0.22)$ & 1.07 \\
\hline N-butyl-N-ethyl-hexanamide & $0.71(0.55-0.93)$ & $4.86(3.16-9.28)$ & $1.97(0.23)$ & 3.65 \\
\hline $\mathrm{N}$-cyclohexyl-N-ethyl-hexanamide & $0.75(0.60-0.92)$ & $3.23(2.31-5.41)$ & $2.58(0.32)$ & 2.11 \\
\hline N-ethyl-N-phenyl-hexanamide & $0.98(0.76-1.23)$ & $3.55(2.57-6.01)$ & $2.94(0.43)$ & 1.06 \\
\hline N-butyl-N-methyl-hexanamide & $1.65(1.36-1.99)$ & $4.69(3.54-7.59)$ & $3.63(0.56)$ & 1.52 \\
\hline $\mathrm{N}, \mathrm{N}$-diallyl-hexanamide & $3.04(2.45-3.94)$ & $12.29(8.12-25.22)$ & $2.71(0.41)$ & 0.37 \\
\hline (E)-N,N-di-(2-methylpropanyl)-2-hexenamide & $1.66(1.04-2.09)$ & $5.05(3.75-10.72)$ & $3.41(0.85)$ & 0.01 \\
\hline (E)-N-n-butyl-N-ethyl-2-hexenamide & $2.40(1.75-2.81)$ & $5.76(4.65-9.54)$ & $4.31(0.99)$ & 0.47 \\
\hline (E)-N-cyclohexyl-N-ethyl-2-hexenamide & $4.16(3.69-4.62)$ & $7.42(6.23-10.75)$ & $6.52(1.30)$ & 0.60 \\
\hline
\end{tabular}

${ }^{a} \mathrm{LD}_{50}$ and $\mathrm{LD}_{95}$ values are in units of micrograms of pesticide per mosquito.

${ }^{b} 95 \%$ CI, toxicity of repellent is considered significantly different when the $95 \%$ CI fails to overlap.

The modes of action of the carboxamides tested here are currently unknown. However, it has been reported that the mode of action of carboxamide tebufenpyrad [N-(4-tert-butyl-benzyl)-4-chloro-3ethyl-1-methylpyrazole-5-carboxamide] is a mitochondrial electron transport inhibitor (METI) (Marcic 2005, Van Pottelberge et al. 2008). Sixteen of the 33 experimental carboxamides had significantly lower $\mathrm{LD}_{50}$ values than DEET $\left(\mathrm{LD}_{50}=2.69 \mu \mathrm{g} /\right.$ mosquito $)$, and 8 were especially toxic, with $\mathrm{LD}_{50}$ values $<1$ $\mu \mathrm{g} /$ mosquito. Based on $\mathrm{LD}_{95}$ value, N-ethyl-2-methylN-phenyl-benzamide was the most toxic compound tested $\left(\mathrm{LD}_{95}=1.82 \mu \mathrm{g} / \mathrm{mosquito}\right)$, suggesting that carboxamides might serve as novel toxicants for mosquito control. However, greater carboxamide concentrations would be needed because the $\mathrm{LD}_{50}$ values were much grater than permethrin $\left(\mathrm{LD}_{50}=0.00014\right.$ $\mu \mathrm{g} /$ mosquito; Pridgeon et al. 2007). Whether these carboxamides are also mitochondrial electron transport inhibitors and/or efficacious against pyrethroidresistant mosquitoes merit further study.

\section{Acknowledgments}

We thank Drs. S. M. Valles and M.-Y. Choi (USDA-ARS) for critical reviews of the manuscript; Drs. A. R. Katritzky, Z. Wang, M. Tsikolia, and C. D. Hall (University of Florida) for providing the carboxamides; G. B. White (University of Florida) for suggesting this study; and S. Allan, L. Jefferson, W. Reid, N. Newlon, N. Sanscrainte, W. Reid, H. Furlong, G. Allen, and M. H. Brown (USDA-ARS) for providing mosquitoes and technical assistance. This study was supported by a grant from the Deployed War-Fighter Protection (DWFP) Research Program funded by the U.S. Department of Defense through the Armed Forces Pest Management Board (AFPMB).

\section{References Cited}

Abbott, W. S. 1925. A method of computing the effectiveness of an insecticide. J. Econ. Entomol. 18: 265-267.
Aitken, T. H., W. G. Downs, and R. E. Shope. 1977. Aedes aegypti strain fitness for yellow fever virus transmission. Am. J. Trop. Med. Hyg. 26: 985-989.

Brown, A. W., and R. Pal. 1971. Insecticide resistance in arthropods. Public Health Pap. 38: 1-491.

Coleman, J. C., and D. M. McLean. 1973. Dengue virus transmission by Aedes aegypti mosquitoes following intrathoracic inoculation. Am. J. Trop. Med. Hyg. 22: 124129.

Cui, F., M. Raymond, and C. L. Qiao. 2006. Insecticide resistance in vector mosquitoes in China. Pest Manag. Sci. 62: 1013-1022.

de Filippis, A. M., R. M. Nogueira, H. G. Schatzmayr, D. S. Tavares, A. V. Jabor, S. C. Diniz, J. C. Oliveira, E. Moreira, M. P. Miagostovich, E. V. Costa, and R. Galler. 2002. Outbreak of jaundice and hemorrhagic fever in the Southeast of Brazil in 2001: detection and molecular characterization of yellow fever virus. J. Med. Virol. 68: 620 627.

Degallier, N., J. P. Herve, A. P. Travassos da Rosa, and G. C. Sa. 1988. [Aedes aegypti (L.): importance of its bioecology in the transmission of dengue and other arboviruses. I]. Bull. Soc. Pathol. Exot. Filiales 81: 97-110.

Flores, A. E., J. S. Grajales, I. F. Salas, G. P. Garcia, M. H. Becerra, S. Lozano, W. G. Brogdon, W.C.T. Black, and B. Beaty. 2006. Mechanisms of insecticide resistance in field populations of Aedes aegypti (L.) from Quintana Roo, Southern Mexico. J. Am. Mosq. Control. Assoc. 22: 672-677.

Fouque, F., and R. Carinci. 1996. [Aedes aegypti in French Guiana. Some aspects of history, general ecology and vertical transmission of the dengue virus]. Bull. Soc. Pathol. Exot. 89: 115-119.

Gillett, J. D., and R. W. Ross. 1955. The laboratory transmission of yellow fever by Aedes (Stegomyia) aegypti (Linnaeus) from Malaya. Ann. Trop. Med. Parasitol. 49: 63-65.

Gubler, D. J. 1989. Aedes aegypti and Aedes aegypti-borne disease control in the 1990s: top down or bottom up. Charles Franklin Craig Lecture. Am. J. Trop. Med. Hyg. 40: $571-578$.

Hamdan, H., M. Sofian-Azirun, W. A. Nazni, and H. L. Lee. 2005. Insecticide resistance development in Culex quinquefasciatus (Say), Aedes aegypti (L.) and Aedes albop- 
ictus (Skuse) larvae against malathion, permethrin and temephos. Trop. Biomed. 22: 45-52.

Jirakanjanakit, N., P. Rongnoparut, S. Saengtharatip, T. Chareonviriyaphap, S. Duchon, C. Bellec, and S. Yoksan. 2007. Insecticide susceptible/resistance status in Aedes (Stegomyia) aegypti and Aedes (Stegomyia) albopictus (Diptera: Culicidae) in Thailand during 2003-2005. J. Econ. Entomol. 100: 545-550.

Katritzky, A. R., Z. Wang, S. Slavov, M. Tsikolia, D. Dobchev, N. G. Akhmedov, C. D. Hall, U. R. Bernier, G. G. Clark, and K. J. Linthicum. 2008. Synthesis and bioassay of improved mosquito repellents predicted from chemical structure. Proc. Natl. Acad. Sci. U.S.A. 105: 7359-7364.

Licciardi, S., J. P. Herve, F. Darriet, J. M. Hougard, and V. Corbel. 2006. Lethal and behavioural effects of three synthetic repellents (DEET, IR3535 and KBR 3023) on Aedes aegypti mosquitoes in laboratory assays. Med. Vet. Entomol. 20: 288-293.

Liu, H., E. W. Cupp, K. M. Micher, A. Guo, and N. Liu. 2004. Insecticide resistance and cross-resistance in Alabama and Florida strains of Culex quinquefaciatus. J. Med. Entomol. 41: 408-413.

Malavige, G. N., S. Fernando, D. J. Fernando, and S. L. Seneviratne. 2004. Dengue viral infections. Postgrad. Med. J. 80: 588-601.

Marcic, D. 2005. Sublethal effects of tebufenpyrad on the eggs and immatures of two-spotted spider mite, Tetranychus urticA. Exp. Appl. Acarol. 36: 177-185.

Mattingly, P. F. 1967. Aedes aegypti and other mosquitos in relation to the dengue syndrome. Bull. W.H.O. 36: 533535.

Onyango, C. O., A. A. Grobbelaar, G. V. Gibson, R. C. Sang, A. Sow, R. Swaneopel, and F. J. Burt. 2004a. Yellow fever outbreak, southern Sudan, 2003. Emerg. Infect. Dis. 10: $1668-1670$.

Onyango, C. O., V. O. Ofula, R. C. Sang, S. L. Konongoi, A. Sow, K. M. De Cock, P. M. Tukei, F. A. Okoth, R. Swanepoel, F. J. Burt, et al. 2004b. Yellow fever outbreak, Imatong, southern Sudan. Emerg. Infect. Dis. 10: 1063-1068.

Philip, C. B. 1962. Transmission of yellow fever virus by aged Aedes aegypti and comments on some other mosquitovirus relationships. Am. J. Trop. Med. Hyg. 11: 697701.
Pinto Severo, O. 1955. [Campaign of eradication of Aedes aegypti in the Americas; its organization, development and results since December 1954.]. Bol. Oficina Sanit. Panam. 38: 378-398.

Pridgeon, J. W., K. M. Meepagala, J. J. Becnel, G. G. Clark, R. M. Pereira, and K. J. Linthicum. 2007. Structure-activity relationships of 33 piperidines as toxicants against female adults of Aedes aegypti (Diptera: Culicidae). J. Med. Entomol. 44: 263-269.

Rudnick, A. 1967. Aedes aegypti and haemorrhagic fever. Bull. W.H.O. 36: 528-532

Soper, F. L. 1967. Aedes aegypti and yellow fever. Bull. W.H.O. 36: 521-527.

Teixeira Mda, G., C. Costa Mda, M. L. Barreto, and E. Mota. 2005. Dengue and dengue hemorrhagic fever epidemics in Brazil: what research is needed based on trends, surveillance, and control experiences? Cad Saude Publ. 21: 1307-15.

Valero, N. 2003. [Yellow fever in Venezuela]. Invest. Clin. 44: 269-271.

Van Pottelberge, S., T. Van Leeuwen, R. Nauen, and L. Tirry. 2008. Resistance mechanisms to mitochondrial electron transport inhibitors in a field-collected strain of Tetranychus urticae Koch (Acari: Tetranychidae). Bull Entomol. Res. 10: 1-9.

Vasconcelos, P. F., A. P. Rosa, S. G. Rodrigues, E. S. Rosa, H. A. Monteiro, A. C. Cruz, V. L. Barros, M. R. Souza, and J. F. Rosa. 2001. Yellow fever in Para State, Amazon region of Brazil, 1998-1999: entomologic and epidemiologic findings. Emerg. Infect. Dis. 7: 565-569.

Xue, R. D., D. R. Barnard, and A. Ali. 2001. Laboratory and field evaluation of insect repellents as oviposition deterrents against the mosquito Aedes albopictus. Med. Vet. Entomol. 15: 126-131.

Xue, R. D., A. Ali, and D. R. Barnard. 2003. Laboratory evaluation of toxicity of 16 insect repellents in aerosol sprays to adult mosquitoes. J. Am. Mosq. Control Assoc. 19: 271-274.

Yaicharoen, R., R. Kiatfuengfoo, T. Chareonviriyaphap, and P. Rongnoparut. 2005. Characterization of deltamethrin resistance in field populations of Aedes aegypti in Thailand. J. Vector. Ecol. 30: 144-150.

Received 6 November 2008; accepted 17 April 2009. 